\title{
MEMAKNAI BAHASA VISUAL PADA ILUSTRASI BERGAMBAR SOEHARTO DI SAMPUL MUKA MAJALAH TEMPO
}

\author{
Danendro Adi \\ Visual Communication Design, School of Design, BINUS University, \\ Jl. KH Syahdan No. 9 Palmerah - Jakarta 11480, \\ dadi@binus.edu
}

\begin{abstract}
Illustration on publication media has become a form to deliver message visually that is more powerful than written message. Illustration is able to build readers perception and attention. Illustration on the cover of a magazine needs the writer and the artist synergy in order to create artwork that deliver messages in a certain visual language at the same time gives identity to the magazine. This paper will discuss the illustrations and visual language used and the extent of utilization and the impact of the illustrations of the readers and the media in which the illustration shown. Illustrations of the former President Soeharto on the cover of Tempo magazine since 1998 edition, after his retirement until his death in 2008 become the case study and the cover of the magazines during the New Order era as the comparison. The research method used in this study is qualitative research methods including data collection in the form of a literature study and interviews, followed by analyzing the data findings. This study should obtain a clearer picture on how illustrations affect the news media and the relation to the audience's perception about the character in the illustration.
\end{abstract}

Keywords: illustration, visual language

\begin{abstract}
ABSTRAK
Ilustrasi pada media publikasi telah menjadi bentuk penyampaian pesan lewat bertutur secara visual yang lebih kuat dibandingkan tulisan. Ilustrasi dapat membangun persepsi bagi yang melihatnya. Ilustrasi pada sampul muka sebagai pemberi identitas sekaligus menarik perhatian tidak terlepas dari peran sinergi antara penulis dan seniman dalam menghasilkan karya yang sanggup menyampaian pesan dalam bahasa visual. Tulisan ini akan membahas ilustrasi dan bahasa visual yang digunakan serta sejauh mana pemanfaatan dan dampak yang dihasilkan dari ilustrasi terhadap pembaca dan media di mana ilustrasi tersebut ditampilkan. Ilustrasi bergambar mantan presiden Soeharto pada sampul muka majalah Tempo edisi tahun 1998 pasca pengunduran dirinya hingga meninggal di tahun 2008 dijadikan studi kasus dan sampul muka bergambar Soeharto masa Orde Baru sebagai pembanding. Metode penelitian yang digunakan dalam penulisan ini metode penelitian kualitatif meliputi pengumpulan data berupa studi literatur dan wawancara yang dilanjutkan dengan analisa data temuan. Hingga pada akhir tulisan bisa didapatkan gambaran yang lebih jelas dari pengaruh ilustrasi di media berita dan kaitannya dengan persepsi yang berusaha ditimbulkan dari penokohan karakternya.
\end{abstract}

Kata kunci: Ilustrasi, bahasa visual 


\section{PENDAHULUAN}

Majalah dan surat kabar telah lama menjadi bagian dari budaya global yang secara umum menyajikan pemberitaan, opini politik, artikel fitur gaya hidup dan budaya, serta liputan olahraga, sebagai media penyampaian informasi yang menyangkut kepentingan publik. Pembaca memiliki ketertarikan yang cukup besar pada dinamika politik dan ekonomi karena menyangkut kelangsungan masa depan masyarakat luas termasuk pembaca media itu sendiri. Kemampuan media dalam penyebarluasan informasi di Indonesia telah mengalami perubahan semenjak runtuhnya rezim Orde Baru, ditandai dengan pengunduran diri Soeharto sebagai presiden Republik Indonesia, yang dibarengi dengan tuntutan akan keleluasaan untuk menyampaikan dan memperoleh informasi yang menyangkut kepentingan publik.

Pada masa Orde Baru semua media berita secara langsung dikendalikan oleh pemerintah yang berkuasa. Media sebagai corong pemerintah mengakibatkan segala informasi yang akan disampaikan kepada masyarakat harus melalui filter Departemen Penerangan dan persetujuan pemerintah pada masa itu. Seperti yang terjadi saat pembredelan majalah Tempo tahun 1994, setelah majalah yang pertama kali terbit tahun 1971 ini memuat tulisan terkait pembelian kapal perang dari Jerman Timur oleh BJ Habibie (Gambar 1). Pemberitaan tersebut dianggap tidak menyenangkan para pejabat militer dan Pencabutan Surat Ijin Penerbitan pun dilakukan dengan alasan untuk menjaga stabilitas bangsa. Pembredelan tersebut bukanlah yang kali pertama. Sebelumnya pada tahun 1982, Tempo pernah di bredel dengan alasan yang hampir sama: Pemerintah tidak senang dengan isi pemberitaannya.

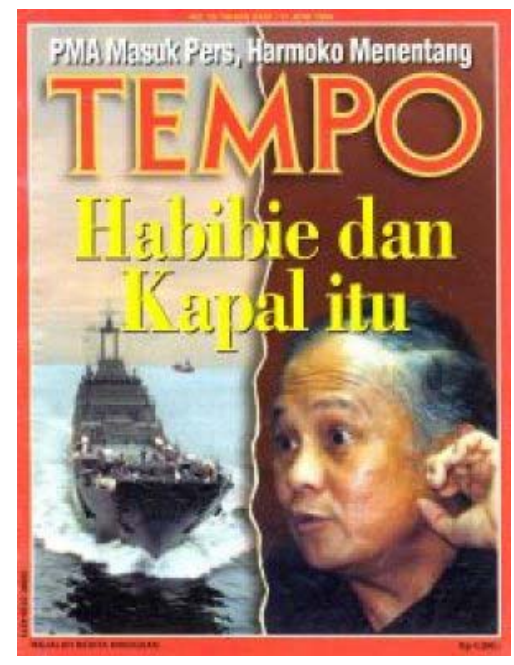

Gambar 1 Pemberitaan di edisi 11 Juli 1994 yang mengakibatkan pembredelan (Sumber: Tempo)

Setelah masa reformasi politik dan ekonomi tahun 1998 segala yang menyangkut isi dan pemberitaan tidak lagi dikendalikan oleh pemerintah. Dibalik perisai Kebebasan Pers, media cetak dan elektronik berhak menyajikan segala sesuatunya dalam bentuk penulisan, fotografi maupun ilustrasi selama tidak bertentangan dengan kaidah jurnalistik, tanpa perlu dihantui pembredelan. Sampul muka majalah Tempo dengan segala ciri uniknya telah memberi identitas dan penarik perhatian. Bahkan bukan tidak mungkin angka penjualan sebuah edisi dipengaruhi oleh visualisasi pesan pada sampul mukanya. Sejalan dengan perubahan iklim politik di Indonesia, Ilustrasi pada sampul muka majalah Tempo telah mengalami perubahan dari visualisasi yang penuh keterbatasan menjadi media eksplorasi kreativitas dalam penyampaian pesan yang dapat berupa kritik, satir dan opini. 
Mantan Presiden Soeharto pun tidak luput dari sasaran olah kreatifitas para perancang visual dari media yang pernah menjadi "musuhnya" saat berkuasa. Setelah pengunduran dirinya sebagai Presiden, Soeharto masih kerap menjadi bahan pemberitaan karena terkati beberapa kasus selama masih menjabat sebagai presiden. Diantaranya terkait dugaan korupsi, penyelesaian kasus hukum, hingga usaha menyeretnya ke pengadilan. Ia juga pernah diberitakan menuntut majalah Time Asia senilai US\$ 27 miliar atas pemberitaan mengenai kekayaan keluarganya yang dianggap tidak benar. Kebebasan berekspresi pun menghasilkan karya ilustrasi kontemporer yang bersandingan saling mendukung dengan tulisan artikel dimana ilustrasi itu ditempatkan. Lebih jauh lagi, ilustrasi turut berperan dalam mengisi imajinasi pembacanya karena kesanggupannya menghasilkan bentuk yang multi tafsir atau kandungan tertentu yang boleh berbeda antara pemirsa yang satu dengan lainnya.

Dengan segala dinamika yang telah dialami majalah berita Tempo dan hubungan yang tidak harmonis dengan pemerintah masa Orde Baru, yang selama 32 tahun seolah menyumbat saluran kreativitas, menjadikan media berita ini menarik untuk diamati. Ditambah lagi dengan era kebebasan pers yang memberikan peluang untuk terciptanya karya ilustrasi yang lebih "berani" bahkan kontroversial semakin menjadi daya tarik untuk diteliti.

\section{METODE}

Penulisan ini disusun menggunakan pendekatan studi literatur untuk mendapatkan data-data pendukung serta mencari kerangka teori guna menguatkan hasil penulisan. Kemudian setelah data-data didapatkan maka akan dilakukan analisa data reflektif dimana penulis akan mencari makna yang terkandung dari hasil pengumpulan data yang telah dilakukan untuk diperbandingkan dengan bentuk pengaplikasian obyek penelitan pada media editorial sebagai studi kasus sehingga dapat diperoleh kesimpulan data yang rasional dan ilmiah.

\section{HASIL DAN PEMBAHASAN}

Menurut Habershon (dalam Hall, 2011) ilustrasi editorial harus memenuhi kriteria sebagai berikut: (1) Ilustrasi harus menampilkan visual hook atau memiliki daya tarik secara visual di mana dapat menarik perhatian pembaca tanpa perlu terlebih dahulu mengetahui isi tulisan atau atau artikel dimana ilustrasi tersebut disandingkan. Bila hal tersebut terjadi, maka selanjutnya pembaca akan tertarik pula untuk membaca headline atau tulisannya. (2) Ilustrasi harus dapat menyimpulkan gagasan atau esensi dari sebuah cerita. (3) Ilustrasi dapat berdiri sendiri namun memiliki fungsi yangsama seperti halnya bila disandingkan dengan artikel atau headline.

Pemuatan gambar pada media berita untuk memenuhi kebutuhan estetika, lebih jauh lagi pendukung tulisan atau berita, tidak terbatas pada penerapan gambar dalam bentuk fotografi namun juga segala bentuk gambar dalam berbagai teknis penciptaannya seperti ilustrasi dengan tehnik tradisional maupun penggunaan media digital. Ilustrasi pada sampul muka juga harus dapat mewakili ide dari inti cerita pada artikel utama pada edisi tersebut dan memilik kekuatan yang sama dengan headline yang tertulis pada sampul majalahnya. Sebagian besar ilustrasi pada sampul muka majalah Tempo menggunakan bahasa visual metaphore yaitu bentuk ilustrasi yang lebih konseptual untuk menerangkan ide yang lebih simbolik seperti yang dijelaskan pada buku Illustration: A Theoretical \& Contextual Perspective. Bahasa visual metaphore sangat tepat untuk menghasilkan bentuk rekonstruksi secara visual yang mencoba menggambarkan suatu peristiwa hasil rekaan yang tidak dapat dihasilkan lewat teknik fotografi sekalipun. Bentuk ilustrasi dengan bahasa visual metaphore yang secara bentuk disebut Conceptual di mana dapat menerapkan bentuk metafora atau bentuk yang dapat memiliki makna yang berbeda dengan bentuk yang divisualkan (Male, 2007). 
Bahasa visual lain pada ilustrasi adalah Literal Representation atau menampilkan bentuk visual yang sebenarnya, tanpa ada ubahan dalam bentuk dan memiliki arti yang sesuai dengan apa yang divisualkan (pictorial truth). Bahasa visual yang jarang diterapkan pada ilustrasi sampul muka majalah tersebut untuk menampilkan bentuk yang secara akurat memvisualisasikan atau mendiskripsikan sesuatu lewat gambar akan suatu kejadian atau bentuk dengan sebenarnya (Male, 2007).

Ilustrasi Editorial kerap menggunakan metode Storytelling yaitu penyampaian pesan berupa visualisasi gagasan, emosi dan pemahaman akan suatu peristiwa yang memberikan interaksi antara pembaca dengan pesan yang disampaikan. Storytelling, seperti yang dijelaskan pada buku Universal Principles of Design merupakan cara penyampaian pesan yang sengat humanis, merupakan cara yang sudah dipakai manusia dari generasi ke generasi dalam penyampaian pengetahuan hingga kini. Penggunaan pendekatan storytelling dapat menarik perhatian pembaca akan sebuah desain atau ilustrasi, menciptakan emosi tertentu, maupun untuk menyampaikan muatan tertentu. Sehingga bila pesan dapat tersampaikan melalui storytelling maka akan diperoleh pengalaman personal akan informasi yang disampaikan (Lidwell, 2010).

\section{Soeharto dan sampul muka.}

Setelah pengunduran dirinya sebagai Presiden tahun 1998, Soeharto masih kerap menjadi bahan pemberitaan karena terkait beberapa kasus selama masih menjabat sebagai presiden. Diantaranya terkait dugaan korupsi, penyelesaian kasus hukum, hingga usaha menyeretnya ke pengadilan. Ia juga pernah diberitakan menuntut majalah Time Asia senilai US\$ 27 miliar atas pemberitaan mengenai kekayaan keluarganya yang dianggap tidak benar. Sebelumnya Soeharto pernah muncul pada sampul muka majalah Time yaitu saat revolusi tahun 1965, Soeharto belum menjadi Presiden saat itu, dan saat menjelang reformasi politik tahun 1998 (Gambar 2).
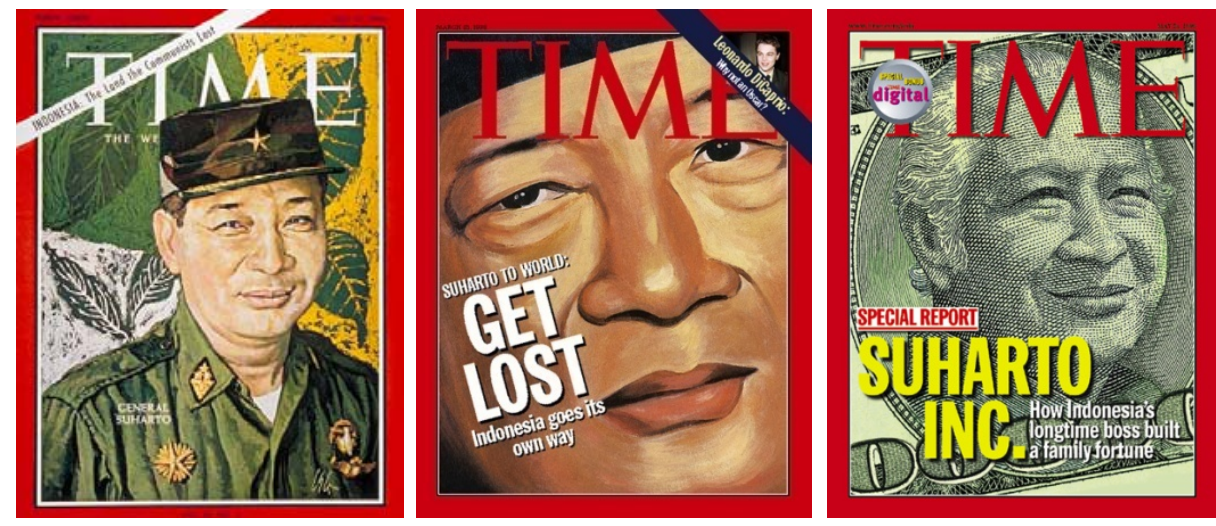

Gambar 2 Sampul muka majalah Time bergambar Soeharto

(Sumber: Tempo)

Sejak tahun 1998 hingga meninggalnya di tahun 2008, wajahnya muncul pada sampul muka majalah Tempo sekaligus coverstory sebanyak 21 edisi. Jumlah yang cukup banyak mengingat pada masa itu ia tidak lagi menjadi penguasa di republik ini. Sebagai perbandingan, semenjak majalah Tempo pertama kali terbit tahun 1971 hingga di bredel tahun 1994, wajah Soeharto yang kala itu masih menjabat sebagai presiden hanya diabadikan di sampul muka sebanyak 21 edisi. Wajah Soeharto baru mengisi sampul muka pada edisi ke 20 (17 Juli 1971) yang betajuk: "Struktur Politik Dirombak atau Dipermak" berisi tulisan mengenai pasca kemenangan golkar pada pemilu 1971 (Gambar 3). Wajah sang Ibu Negara, Tien Soeharto, justru lebih dahulu muncul di sampul muka yaitu pada edisi ke 8 (24 April 1971) dengan tajuk: “Njonja-Njonja di Pusat Republik” (Gambar 4). 


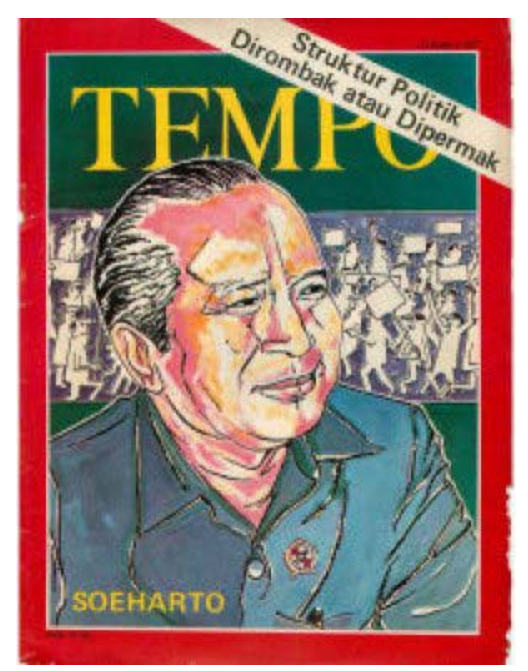

Gambar 3 Sampul muka pertama bergambar Presiden Soeharto (Sumber: Tempo)

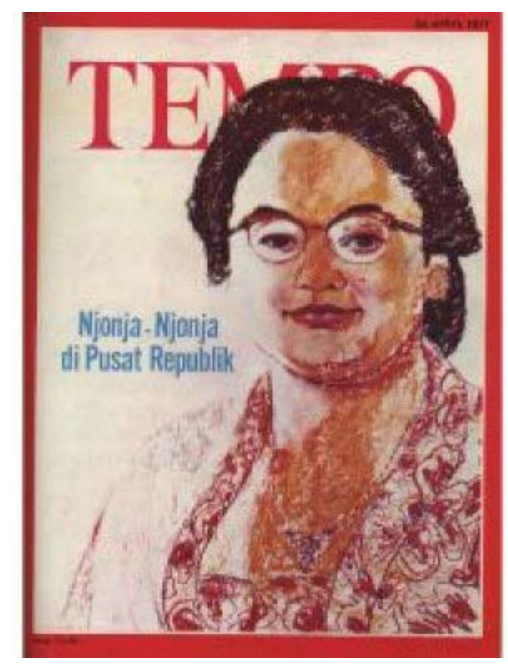

Gambar 4 Sampul muka bergambar Ibu Negara

(Sumber: Tempo)

Tidak ada penjelasan mengenai langkanya sang Kepala Negara dijadikan coverstory. Bisa jadi kerena sedikitnya pemberitaan mengenai Soeharto yang layak untuk dijadikan tajuk utama pada waktu itu, atau justru sebagai bukti adanya pengawasan ketat pemerintah terhadap muatan pemberitaan sehingga Tempo lebih berhati-hati.

\section{Soeharto dan Identitas Diri pada Sampul Muka}

Dari 21 edisi majalah Tempo dengan sampul muka bergambar Soeharto hampir tidak pernah ditampilkan dalam bentuk penokohan selain sebagai negarawan dan menampilkan kewibawaannya. Penokohan tersebut didukung dengan gambar atribut yang dipakai berupa pakaian formil seperti yang biasa dipakai saat acara resmi maupun kenegaraan dengan setelan jas atau safari dan sesekali berpeci. 

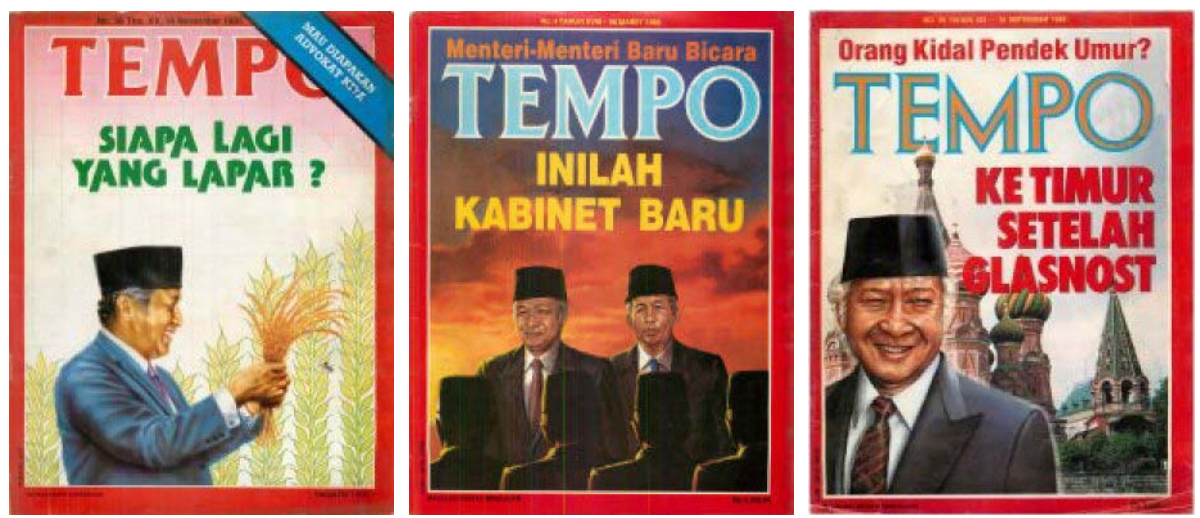

Gambar 4 Penggambaran Soeharto yang lazim terdapat pada sampul muka majalah Tempo era Orde Baru

(Sumber: Tempo)

Soeharto pernah mengenakan atribut yang lain untuk memunculkan penokohan yang berbeda. Seperti pada majalah edisi Maret 1973 yang berisi artikel tentang menjelang Sidang Umum MPR hasil pemilu dengan salah satu agendanya memilih wakil presiden. Pada sampul majalah tersebut Soeharto digambarkan mengenakan Sorjan, pakaian untuk acara resmi khas Yogyakarta, memperlihatkan identitas dirinya yang berasal dari suku Jawa (Gambar 5). Sementara berdiri di sebelahnya sembari menjulurkan lengan seperti sedang menawarkan diri, calon wakil presiden Sri Sultan Hamengkubuono IX, Sultan Yogyakarta. Ilustrasi ini menjadikan Soeharto terlihat lebih berwibawa karena pada ilustrasi tersebut menampilkan gesture Sultan Yogyakarta yang justru seolah meminta untuk disandingkan dengannya.

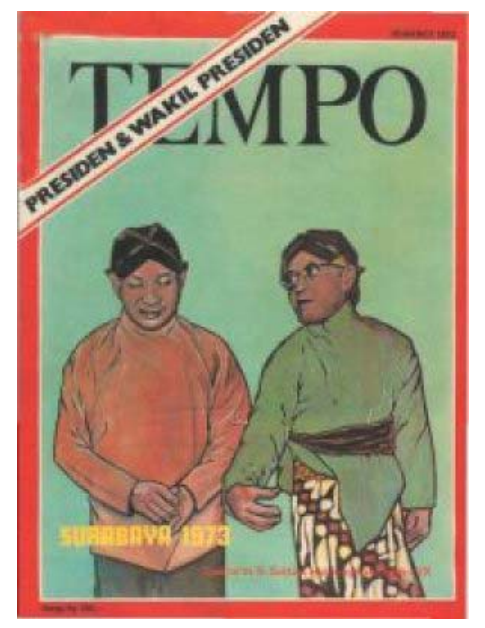

Gambar 5. Sampul muka bergambar Presiden Soeharto mengenakan Sorjan.

Satu-satunya yang menggambarkan Presiden Soeharto dengan identitas asal daerahnya

(Sumber: Tempo)

Soeharto pernah divisualisasikan seperti rakyat biasa yaitu pada sampul majalah edisi 9 November 1974 dengan judul utama "Hormat Untuk Seorang Anak Desa". Pada sampul majalah tersebut Soeharto diilustrasikan mengenakan pakaian sederhana lengkap dengan caping, penutup kepala pelindung panas yang biasa dipakai oleh petani di pulau Jawa saat bekerja diladang (Gambar 6). Majalah edisi tersebut berisi artikel tentang Soeharto yang mengungkapkan sebagian dari sejarah hidupnya dihadapan wartawan dalam dan luar negeri. Ilustrasi yang ingin menampilkan kebersahajaan justru sangat tepat untuk mengangkat wibawanya sebagai Presiden dari sebuah negara agraris. 


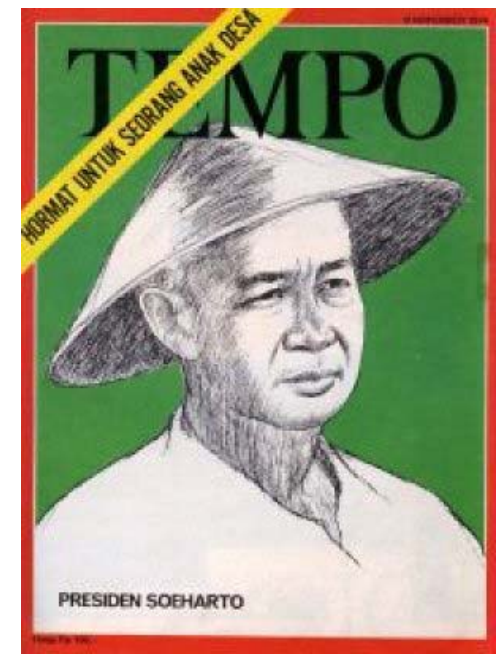

Gambar 6 Sampul muka bergambar Presiden Soeharto dengan atribut yang mewakili masyarakat agraris

(Sumber: Tempo)

Sampul muka majalah Tempo juga pernah menampilkan sosok Soeharto yang Islami sedang mengenakan Ikhram, pakaian yang dikenakan saat menunaikan ibadah Haji atau Umrah, yaitu pada edisi 29 Oktober 1977 bertajuk “Assalamualaikum, Ya Timur Tengah” dan edisi 6 Juli 1991 dengan judul utama "Umat Islam dan Pak Harto" saat ia dan ibu Negara menunaikan ibadah Haji. (Gambar 7). Meskipun Soeharto tidak ditampilkan dengan atributnya sebagai presiden, ilustrasi penokohan dirinya justru terlihat sangat layak berada di sampul muka mengingat ia sebagai kepala Negara yang berpenduduk Muslim terbesar di dunia. Pada kedua sampul muka majalah edisi tersebut name style TEMPO yang berwarna hijau menguatkan pesan yang terdapat pada ilustrasinya. Penyampaian pesan dalam bentuk visual yang diperkuat dengan penerapan warna tertentu memiliki peran penting dalam bidang simbolisme (Purbasari, 2011) karena warna hijau bagi sebagian masyarakat Indonesia diasosiasikan sebagai warna Islami, sekaligus warna yang identik dengan partai politik berbasis Islam pada masa itu.
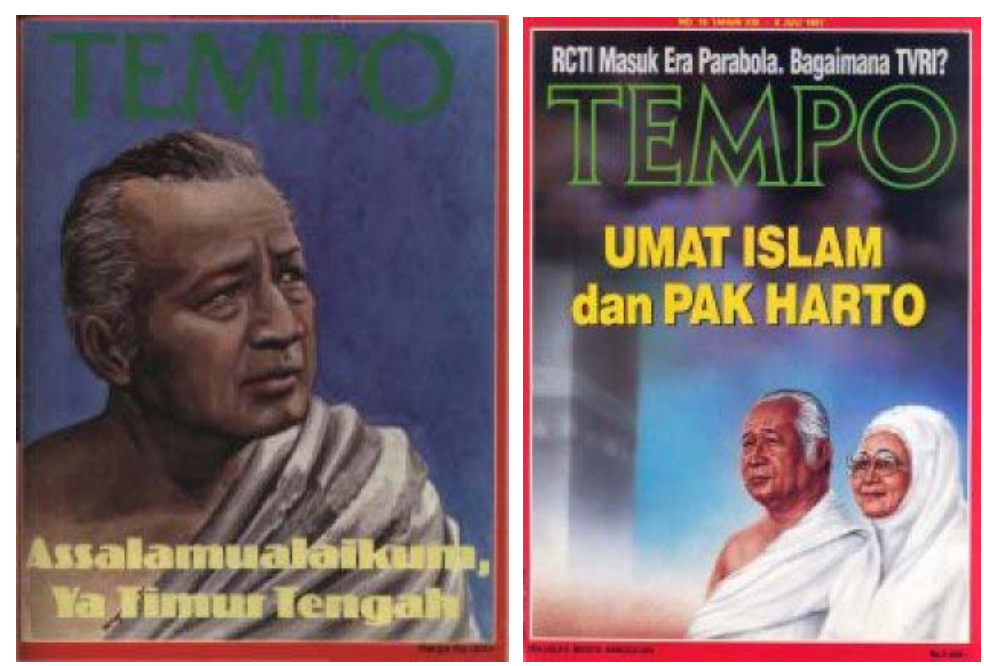

Gambar 7 Sampul muka yang menampilkan sosok Presiden Soeharto sebagai Muslim yang taat (Sumber: Tempo) 


\section{Sampul Muka Bergambar Soeharto Pasca Pengunduran Dirinya Sebagai Presiden}

Setelah pengunduran diri Soeharto dan majalah Tempo terbit kembali tahun 1998, tidak perlu waktu lama untuk menampilkan lagi sosok Soeharto pada sampul muka setelah terakhir kalinya pada edisi 13 Maret 1993. Bahkan sampul muka edisi nomor contoh, sebelum edisi resmi terbit kembali, sudah dihiasi dengan wajah Soeharto dengan headline "Mengapa Soeharto Menantang" yang memuat tulisan mengenai tuntutan Soeharto kepada majalah Time Asia senilai US\$ 27 miliar atas pemberitaan mengenai kekayaan keluarganya yang dianggap tidak benar (Gambar 8).

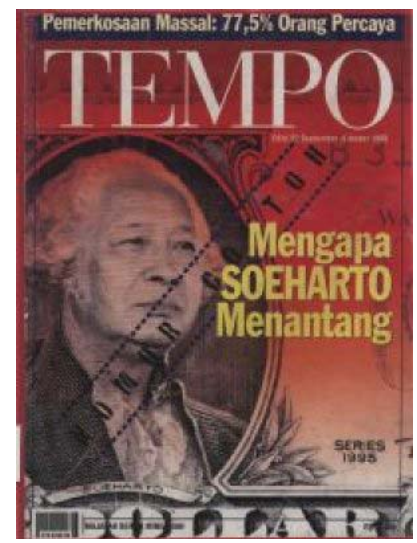

Gambar 8 Sampul muka edisi nomor contoh majalahTempo terbit kembali setelah di bredel tahun 1994

(Sumber: Tempo)

Sebagian besar ilustrasi sampul muka majalah Tempo bergambar Soeharto dibuat dalam bahasa visual metaphor di mana menampilkan sosok Soeharto yang tidak seperti dalam keadaan yang sebenarnya dan bisa menimbulkan interpretasi yang beragam bagi yang melihat, bahkan bisa menimbulkan interpretasi yang bersifat negatif. Sebagian besar sampul muka bergambar Soeharto pada saat itu berkaitan dengan proses hukum yang melibatkan dirinya dibuat dengan bahasa visual metaphore, hal yang tidak lazim saat orde baru. Soeharto bisa ditampilkan dalam sosok yang berbeda untuk memunculkan makna yang tersirat seperti pada edisi 21 Mei 2006 berjudul "Semua Tergantung Soeharto" dengan gaya ilustrasi menyerupai dokumentasi visual pengadilan di Amerika Serikat yang tidak memperbolehkan dokumentasi foto di ruang persidangan (Gambar 8). Ilustrasi menggambarkan suasana pengadilan yang diisi oleh sosok Soeharto sebagai hakim, pengacara, jaksa penuntut hingga terdakwa sebagai opini visual atas ketidakseriusan pemerintah untuk mengadili sang mantan penguasa itu.

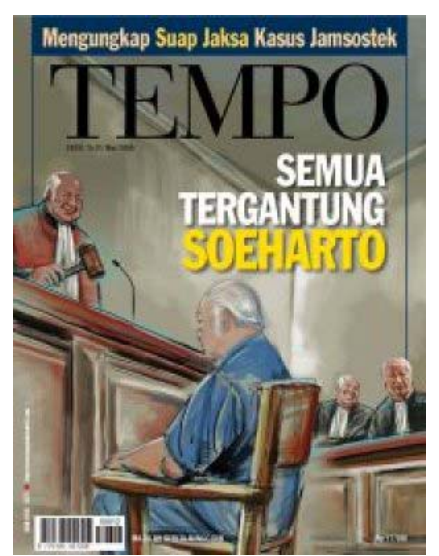

Gambar 8 Kritik pada sampul muka (Sumber: Tempo) 
Pada sampul majalah edisi 28 Mei 2006 bertajuk utama "Membongkar 7 Yayasan: Harta Soeharto", Soeharto divisualkan menyerupai pelaut era para perompak menguasai jalur perdagangan bangsa eropa abad 16-17, dikenali lewat visualisasi pakaian yang dikenakan dan benda-benda disekitarnya, sedang melindungi peti hartanya (Gambar 9). Ilustrasi menggambarkan Soeharto yang terlihat kepayahan melindungi treasure chest yang ada di sisinya sebagai visual metaphore atas artikel utama mengenai pengusutan harta kekayaan Soeharto oleh Kejaksaan Agung. Ilustrasi tersebut tidak mengarahkan posisi Suharto sebagai perompak maupun sebagai korban perampokan namun persepsi negatif yang timbul akibat pemberitaan di media pada saat itu dapat dengan mudahnya memposisikan Soeharto sebagai pihak yang bermasalah.

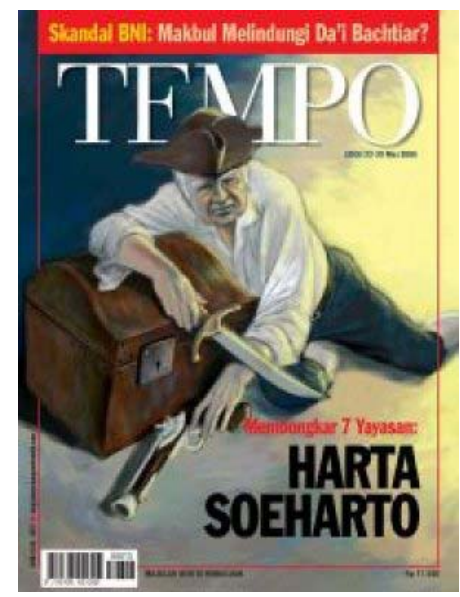

Gambar 9 Visualisasi yang bisa menimbulkan beragam interpretasi makna (Sumber: Tempo)

Soeharto pernah juga di visualisasikan sebagai orang yang tak lagi berdaya. Hal yang bertolak belakang dengan citranya sebagai orang yang pernah sangat berkuasa di Indonesia. Ia digambarkan sedang duduk di kursi roda, mengenakan sarung, berkemeja sederhana dan syal yang menguatkan kesan akan kondisi fisiknya yang menua dan tak lagi bugar. Penggambaran tersebut menyerupai kondisi fisik Soeharto sebenarnya saat itu, seperti yang juga biasa ditampilkan di berbagai nmedia cetak dan elektronik. Hanya saja, pada kedua sampul muka majalah Tempo yang terbit berurutan tersebut, ilustrasi di buat dengan bahasa visual metaphore untuk menguatkan tulisan yang menjadi tajuk utama pada edisi-edisi tersebut (Gambar 10).
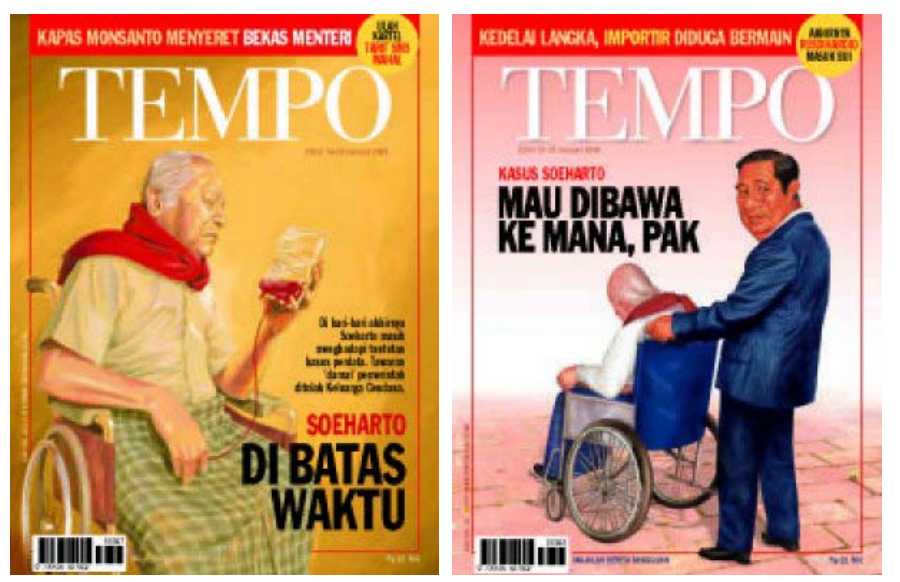

Gambar 10 Penggambaran Soeharto menjelang akhir hayatnya (Sumber: Tempo) 
Pada 20 januari 2008 edisi yang berjudul "Suharto di Batas Waktu” dengan ilustrasi Soeharto yang sedang menatap ke benda yang menyerupai botol infus yang hampir habis dapat menimbulkan persepsi seolah waktu yang tersedia untuk Soeharto sudah semakan pendek, disaat yang sama waktu yang tersedia untuk penyelesaian kasus hukum bagi Soeharto semakin terbatas. Sementara pada majalah Tempo edisi 27 januari 2008 berjudul “Kasus Soeharto: Mau Dibawa Kemana, Pak” dengan tulisan utama mengenai Presiden Susilo Bambang Yudhoyono yang menawarkan penyelesaian kasus Soeharto di luar pengadilan. Pada sampul muka tersebut digambarkan Presiden Susilo Bambang Yudhoyono sedang mendorong kursi roda yang diduduki Soeharto untuk menggambarkan posisi Presiden yang dilematis, di mana keinginannya untuk menyelesaikan kasus hukum yang menjerat Soeharto ditentang oleh pihak keluarga sang mantan presiden. Edisi ini merupakan terakhir kalinya sampul muka majalah Tempo bergambar Soeharto yang terbit saat ia masih hidup.

Pada Tempo edisi 3 Februari 2008 yang terbit tanggal 28 Januari 2008, hanya satu hari setelah meninggalnya Soeharto, karena alasan teknis sampul muka majalah Tempo yang sudah siap edar tersebut dirangkap dengan sampul muka bergambar Soeharto. Ilustrasi pada sampul muka majalah edisi ini merupakan satu-satunya yang dibuat dengan bahasa visual Literal Representation atau menampilkan bentuk visual yang sebenarnya (Pictorial Truth). Soeharto ditampilkan apa adanya, cenderung terlihat sederhana, tidak mengenakan atribut kepresidenan, tanpa pesan atau muatan tertentu. Dengan bingkai pada sampul muka berwarna hitam, biasanya merah, Tempo seolah ikut berkabung dan memberi penghormatan kepada Presiden dengan masa jabatan terlama di republik ini (Gambar 11).

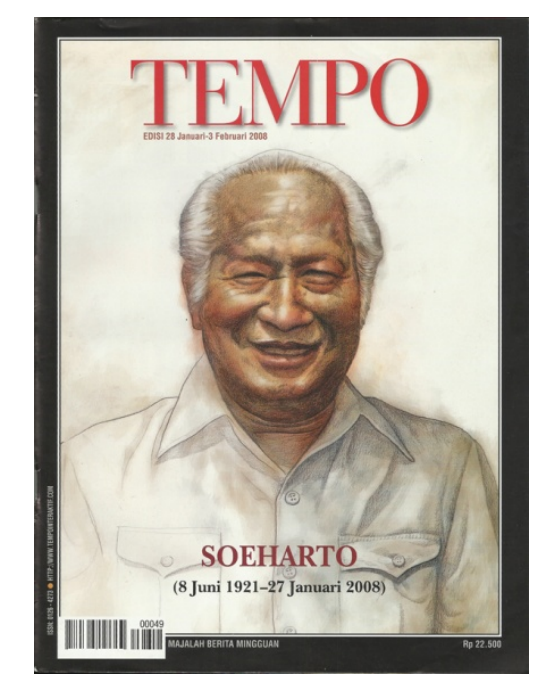

Gambar 11 Edisi penghormatan terakhir kepada Soeharto

(Sumber: Tempo)

Setelah Soeharto meninggal, Tempo membuat Edisi Khusus Soeharto bertajuk "Setelah Dia Pergi" dengan sampul muka berupa ilustrasi keluarga Soeharto yang menyerupai format lukisan perjamuan terakhir Yesus pada murid-muridnya, yaitu The Last Supper karya Leonardo Da Vinci (Gambar 12). Majalah edisi 4 Februari 2008 tersebut menuai banyak kritik karena dianggap memparodikan perjamuan terakhir yang menyinggung perasaan umat kristiani. Atas sampul majalah tersebut, Toriq Hadad selaku Pemimpin Redaksi majalah Tempo saat itu meminta maaf dan menjelaskan bahwa sampul muka terinspirasi oleh bentuk visual dari lukisan The Last Supper karya Leonardo Da Vinci, tidak dengan konteksnya. 


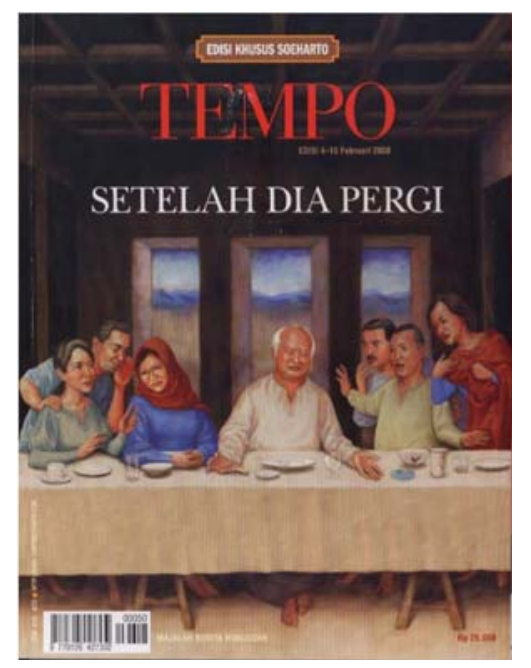

Gambar 11 Sampul muka Edisi Khusus Soeharto (Sumber: Tempo)

Edisi Khusus Soeharto rupanya bukan kesempatan terakhir untuk menampilkan sosok Soeharto pada sampul muka majalah Tempo Edisi Liputan Khusus 100 Tahun Mohammad Natsir (14 Juli 2008) kembali memunculkan Soeharto hanya saja kali ini ia tidak sebagai coverstory. Pada sampul majalah yang juga memunculkan Mohammad Natsir dan Soekarno, Soeharto kembali di tampilkan mengenakan atribut yang kemudian ia dapat dikenali sebagai kepala negara tanpa disertai hal lain yang dapat menimbulkan persepsi yang dapat mengurangi kewibawaan atau hal positif lainnya yang pernah ia sandang. Hal yang tidak pernah ditampilkan pada sampul muka majalah Tempo untuk menggambarkan sosok Soeharto semenjak keruntuhan orde baru. Penggambaran Suharto pada sampul muka majalah edisi tersebut boleh jadi sebagai tanda selesainya "permusuhan" Tempo dengan Soeharto karena memang sudah tidak ada lagi usaha penyelesaian kasus hukum atas dirinya yang dapat dijadikan bahan pemberitaan setelah ia dipanggil menghadap Sang Maha Kuasa.

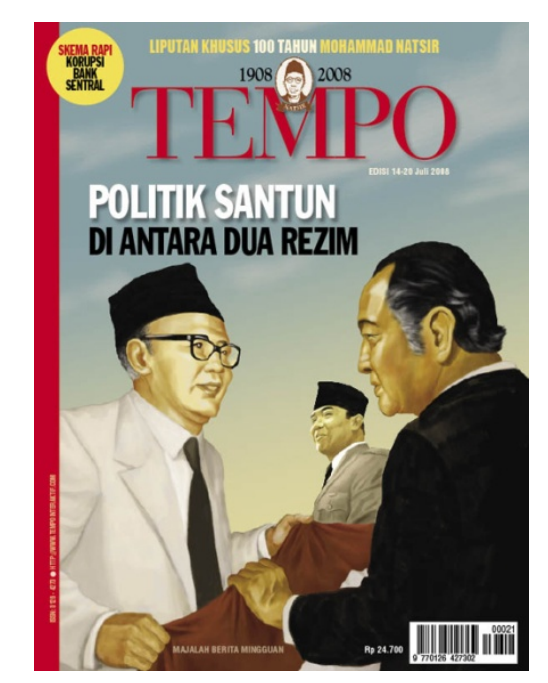

Gambar 11. Soeharto pada sampul muka Edisi Khusus 100 Tahun Mohammad Natsir (Sumber: Tempo) 


\section{SIMPULAN}

Sejalan dengan perubahan iklim politik di Indonesia, Ilustrasi pada sampul muka majalah Tempo telah mengalami perubahan dari visualisasi yang penuh keterbatasan menjadi media eksplorasi kreatifitas dalam penyampaian pesan yang dapat berupa kritik, satir dan opini. Sampul muka majalah Tempo berhasil turut membentuk opini publik melalui bahasa visual yang digunakannya dalam menggambarkan berbagai kasus hukum yang melibatkan mantan presiden Soeharto.

\section{DAFTAR PUSTAKA}

Hall. A. (2011). Illustration. London, UK: Laurence King Publisher.

Lidwell. W. (2010). Holden, K., Butler, J. (Eds). Universal Principles of Design. Massachussetts: Rockport Publisher

Male. A. (2007). Illustration: A Theoretical \& Contextual Perspective. Lausanne, Switzerland: AVA Publishing

Purbasari. M. (2011). Khazana Warna Berdasarkan Alam dan Budaya Nusantara. Jurnal Humaniora, 2(2), 925-1491, ISSN 2087-1236 